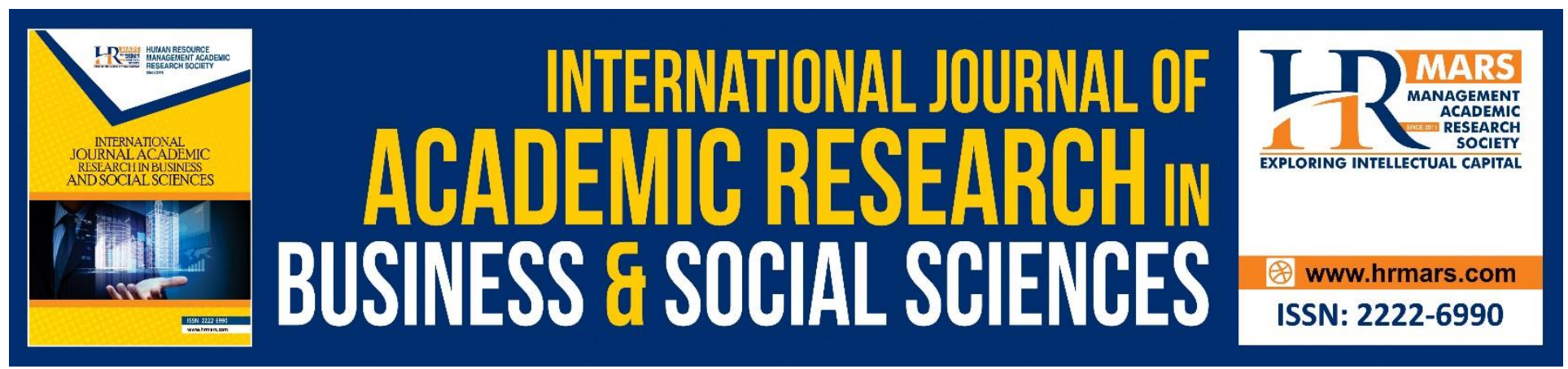

\title{
Disorder of Spanish Verbs Usage in the Production of Grammatical Sentences Based on Pictures
}

\author{
Mariyati Mohd Nor, Nor Shahila Mansor
}

To Link this Article: http://dx.doi.org/10.6007/IJARBSS/v10-i7/7398

DOI:10.6007/IJARBSS/v10-i7/7398

Received: 21 April 2020, Revised: 22 May 2020, Accepted: 29 June 2020

Published Online: 14 July 2020

In-Text Citation: (Nor \& Mansor, 2020)

To Cite this Article: Nor, M. M., \& Mansor, N. S. (2020). Disorder of Spanish Verbs Usage in the Production of Grammatical Sentences Based on Pictures. International Journal of Academic Research in Business and Social Sciences, 10(7), 86-102.

Copyright: (C) 2020 The Author(s)

Published by Human Resource Management Academic Research Society (www.hrmars.com)

This article is published under the Creative Commons Attribution (CC BY 4.0) license. Anyone may reproduce, distribute, translate and create derivative works of this article (for both commercial and non-commercial purposes), subject to full attribution to the original publication and authors. The full terms of this license may be seen at: http://creativecommons.org/licences/by/4.0/legalcode

Vol. 10, No. 7, 2020, Pg. 86 - 102

http://hrmars.com/index.php/pages/detail/IJARBSS

JOURNAL HOMEPAGE

Full Terms \& Conditions of access and use can be found at http://hrmars.com/index.php/pages/detail/publication-ethics 


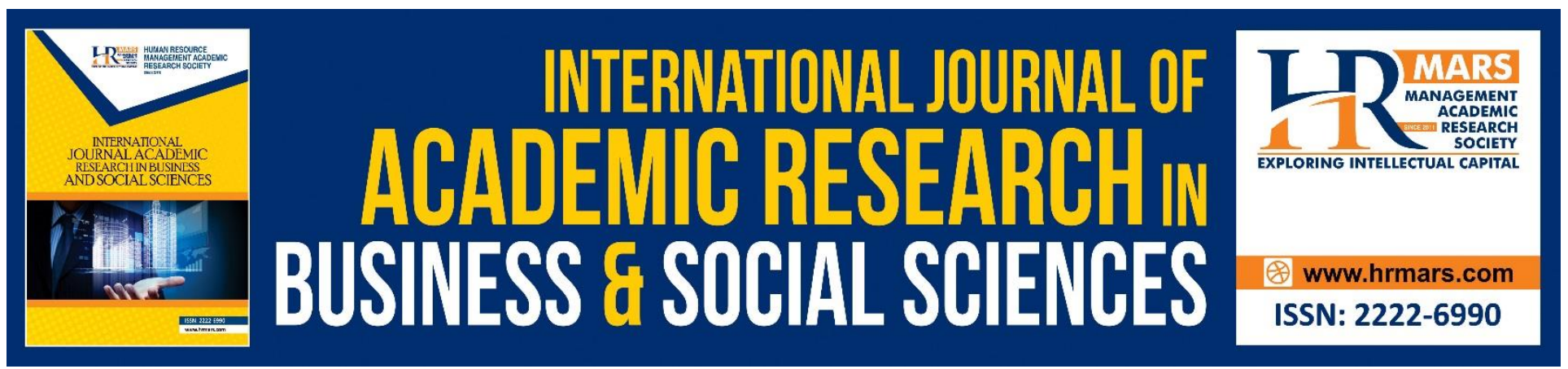

\title{
Disorder of Spanish Verbs Usage in the Production of Grammatical Sentences Based on Pictures
}

\author{
Mariyati Mohd Nor \\ Universiti Pendidikan Sultan Idris \\ Email:mariyati@pbmpu.upsi.edu.my \\ Nor Shahila Mansor \\ Universiti Putra Malaysia \\ Email:nsm@upm.edu.my
}

\begin{abstract}
The aspect of verbs is one of the grammatical aspects that is more complex than the other word classes in learning Spanish as a foreign language. This happens because Spanish is a synthetic relative language that has a high inflection level on verb conjugation. The differences between the verb system in Spanish and the students' native language cause confusion to the students in producing grammatical sentences in writing and lead to error. This study focused on the disorder and verb errors encountered by students in producing Spanish sentences. The respondents consisted of 30 students taking Spanish level I course at Sultan Idris Education University, Perak (UPSI). This study used the descriptive qualitative method with the application of the Taxonomy of Errors by Dulay, Burt \& Krashen (1982) to analyse the data. The results of the study showed that verb disorder occurred particularly on the various forms of verb conjugation based on the subject (doer) and number, the use of verb Ser, Estar, Tener, and reflexive verb of Gustar. This confusion caused grammatical errors, ungrammatical sentences, the addition of unnecessary verbs, reduction of the important elements, incorrect verbs selection, and inaccurate order in sentence construction.
\end{abstract}

Keywords: Disorder, Error, Verb, Grammatical Sentence, Spanish Language, Conjugation.

\section{Introduction}

Teaching Spanish as a foreign language in Malaysia is a very challenging process for language instructors. This is because the grammar system of the Spanish language (SL) is very different from the students' mother tongue which are Malay language, Chinese, Tamil, and other languages of ethnic groups such as Iban, Bidayuh, Dusun and others. These differences caused disorder to occur during the learning process and errors that cannot be avoided (Mariyati, 2018). Many errors occurred throughout the process of learning and the most frequent errors were in the morphology which is word construction, and syntax which is sentence writing. Generally, students who enroll in Spanish as a foreign language course at the Malaysian public universities are students who have no direct 
knowledge of the language. This is because SL is not taught in Malaysian public schools except in international schools. Different backgrounds, motivations, and interests also increase the difficulty of teaching and learning processes to students (Hasmidar, Mardian and Puteri, 2018).

For students whose mother tongue is Malay language, SL confuses because Malay language is a type of agglutinative language that uses many morphemes with verbs and forms new words while changing the meaning and function of the word in a sentence (Karim et al, 2010). While SL uses an inflection-shaped verb system that has three distinct suffixes for each verb and suffix changes for each word. The change of word form is caused by several factors such as the change in the word type, whether it ends with -ar,-er and -ir, the difference of doer or subject (doer who does an action), the number of subjects (singular or plural), and time frame (present, past, future, in progress or subjunctive).

It is difficult for students to master the morphological aspect particularly derivation and conjugation of verbs that are varied and deformed when used. The difference between the mother tongue system and the target language will confuse the learner, however, the similarity will give advantages and ease the teaching and learning process (Brown, 2000). Other than verbs, students are also facing grammatical gender issues and adjectives in SL which are masculine and feminine, gender pairing for adjective and noun, and the number of singular and plural words (Mariyati, 2019). These Spanish language-learning issues and problems clearly show that learning a foreign language among students in Malaysia is not easy. There are many obstacles, constraints, and challenges that a lecturer needs to face to ensure that SL can be well mastered by the students and they can produce accurate and grammatical sentences. According to Edison (2017), the error in SL verb conjugation is not caused by the number of languages spoken by the learner but influenced by the other factors relating to the acquisition of a second language such as linguistic input and individual differences. The study showed that the problem faced by the students in conjugating the SL verb is intraference which is the factor of the language system itself and interference which is the influence of the language spoken by the student is not the dominant factor.

However, the confusion faced by students and error that they committed give useful input to the instructors to produce a method or strategy that can help students to master SL as a foreign language. For example, in a study conducted by Ismail (2016), students used Zone of Proximal Development activities in constructing sentences in SL. His study observed how students were able to solve problems in sentence construction without a teacher or expert assistance. The finding showed that students were able to achieve self-regulation with the help from Google Translate, friends, and books even if the students were novices in SL learning. The study by Shat et al. (2017) was conducted on the strategy to enhance syntax ability among foreign students in learning Malay language. In the study, a structured method was introduced to develop the students' syntax ability from one level to another, ranging from words, phrases, clauses, and sentences. The result of this study was in line with Hassan's opinion (2010) that a language can only be mastered after a trial process. Besides, Holtheuer \& Short (2013) showed that a strategy of error correction done by parents helped the students to use the language better and was able to minimise the verb errors. This is because the errors and mistakes committed by students throughout the learning process in or out of the classroom are a common phenomenon faced by students. 
INTERNATIONAL JOURNAL OF ACADEMIC RESEARCH IN BUSINESS AND SOCIAL SCIENCES Vol. 10, No. 7, July, 2020, E-ISSN: 2222-6990 @ 2020 HRMARS

There are two main objectives in this study which are, 1) analysing disorder of verb usage in SL writing among level I students at Sultan Idris Education University; and 2) provide suggestions to minimise verb error in SL and construct grammatical sentences.

\section{Spanish Verbs}

SL has a very rich inflection, especially on the verbs. Every base verb has a different inflectional ending depending on the doer and the time of action. Spanish verbs have three different inflectional endings which are the suffix -ar, -er, and -ir. For example, the verbs end with suffix -ar are, estar ('to be'), hablar (speaking), estudiar (study), escuchar (hear), bailar (dance), cerrar (close), cantar (singing) and so on. The base form of verbs that end with -er are tener (have), leer (reading), ver (watch), comer (eat), beber (drink) comprender (understand) and verbs with suffix -ir are escribir (writing), dormir (sleep), vivir (stay), recibir (accept), abrir (open), salir (exit), compartir (share) and others.

When these verbs are used in a sentence, they should be amended at the end or conjugated by using the inflection that has been determined depending on the doer and the time of action. For example:

Table 1: Examples of regular verb conjugation at present

\begin{tabular}{|c|c|cc|}
\hline Yo (I) & $\begin{array}{c}\text { Estudio } \\
\text { (I study) }\end{array}$ & $\begin{array}{c}\text { como } \\
\text { (I eat) }\end{array}$ & $\begin{array}{c}\text { Vivo } \\
\text { (I live) }\end{array}$ \\
\hline Tú (you) & $\begin{array}{c}\text { Estudias } \\
\text { (you study) }\end{array}$ & $\begin{array}{c}\text { Comes } \\
\text { (you eat) }\end{array}$ & $\begin{array}{c}\text { Vives } \\
\text { (you live) }\end{array}$ \\
\hline $\begin{array}{c}\text { Él/ella/usted } \\
\text { (he, she and second } \\
\text { person (formal) }\end{array}$ & $\begin{array}{c}\text { Estudia } \\
\text { (Me/she studies) }\end{array}$ & $\begin{array}{c}\text { Come } \\
\text { (Mr., Mrs. studies) } \\
\text { (Mr., Mrs. eats) }\end{array}$ & $\begin{array}{c}\text { Vive } \\
\text { (Mr., Mrs. lives) }\end{array}$ \\
\hline $\begin{array}{c}\text { Nosotros/as (we) } \\
\text { (Mhe lives) }\end{array}$ & $\begin{array}{c}\text { Estudiamos } \\
\text { (we study) }\end{array}$ & $\begin{array}{c}\text { Comemos } \\
\text { (we eat) }\end{array}$ & Vivimos \\
(we live)
\end{tabular}

The inflectional suffix that needs to be changed for each subject and time frame (present, past, future, ongoing, subjunctive) gives a difficulty because verbs in SL are not only in regular form but also irregular in which changes are applied to the base form and need to be changed before being conjugated. For example: 
INTERNATIONAL JOURNAL OF ACADEMIC RESEARCH IN BUSINESS AND SOCIAL SCIENCES Vol. 10, No. 7, July, 2020, E-ISSN: 2222-6990 @ 2020 HRMARS

Table 2: Examples of irregular verb conjugation at present

\begin{tabular}{|c|c|c|c|}
\hline Yo (I) & $\begin{array}{c}\text { Encuentro } \\
\text { (I meet) }\end{array}$ & $\begin{array}{c}\text { Vuelvo } \\
\text { (I come back) }\end{array}$ & $\begin{array}{l}\text { Duermo } \\
\text { (I sleep) }\end{array}$ \\
\hline Tú (you) & $\begin{array}{l}\text { Encuentras } \\
\text { (you meet) }\end{array}$ & $\begin{array}{c}\text { Vuelves } \\
\text { (you come } \\
\text { back) }\end{array}$ & $\begin{array}{l}\text { Duermes } \\
\text { (you sleep) }\end{array}$ \\
\hline $\begin{array}{c}\text { Él/ella/usted } \\
\text { (he, she and second- } \\
\text { person (formal) }\end{array}$ & $\begin{array}{c}\text { Encuentra } \\
\text { (he meets /Mr. /Mrs. } \\
\text { meets) }\end{array}$ & $\begin{array}{c}\text { Vuelve } \\
\text { (he comes } \\
\text { back /Mr. } \\
\text { /Mrs. comes } \\
\text { back) }\end{array}$ & $\begin{array}{c}\text { Duerme } \\
\text { (he sleeps /Mr. /Mrs. sleeps) }\end{array}$ \\
\hline Nosotros/as (we) & $\begin{array}{l}\text { Encontramos } \\
\text { (we meet) }\end{array}$ & $\begin{array}{l}\text { Volvimos } \\
\text { (we come } \\
\text { back) }\end{array}$ & $\begin{array}{l}\text { Dormimos } \\
\text { (we sleep) }\end{array}$ \\
\hline Vosotros/as (you) & $\begin{array}{l}\text { Encontráis } \\
\text { (you meet) }\end{array}$ & $\begin{array}{l}\text { Volvéis } \\
\text { (you come } \\
\text { back) }\end{array}$ & $\begin{array}{c}\text { Dorméis } \\
\text { (you sleep) }\end{array}$ \\
\hline $\begin{array}{c}\text { Ellos/ellas/ustedes } \\
\text { (they, second-person } \\
\text { plural -formal) }\end{array}$ & $\begin{array}{c}\text { Encuentran } \\
\text { (they/ Mr. /Mrs. } \\
\text { meet) }\end{array}$ & $\begin{array}{c}\text { Vuelven } \\
\text { (they/ Mr. } \\
\text { /Mrs. come } \\
\text { back) }\end{array}$ & $\begin{array}{c}\text { Duermen } \\
\text { (they sleep) }\end{array}$ \\
\hline
\end{tabular}

The base verbs in Table 2 show the change in vowel 'o' to be diphthong 'ue' for verb used for the subject 'I, you, he' and 'they' while for the subject ' we' and 'you' the base forms do not change except for the suffix. The change or conjugation of these verbs caused considerable difficulties to the learners because each mistake can bring different meanings and the sentence constructed would not be grammatical. This is in line with the virtue in learning and teaching the aspect of SL morphology which begins with the word groups (root word or base form) and the word conjugation for each verb learned.

All verbs in SL either regular or irregular need to be conjugated, and learners need to be proficient to apply them in sentences. The suffix rules '-o, -as, -a, -amos, -áis', '-an' and '-o, -es, -e,-emos/imos, eis/is, -en' only work on regular verbs that end with -ar, er and -ir. However, for irregular verbs and past tense verbs, future verbs, progressive verbs, subjunctive, or reflexive, these verbs are conjugated with different suffixes. This causes the students to be confused and the disorder arises when the verbs are used in sentences.

Apart from that, level $1 \mathrm{SL}$ students are also confused with the use of verb ser and estar which mean to be in English, but they have different functions in sentences. Ser is used to mention a name, occupation, character/nature of a person/object, the origin, skin colour, time and day, but estar is used to mention the existence of a person/object, emotion, health condition, marital status and action that is taking place. For example, different use of Ser and Estar can be seen in the table below: 
INTERNATIONAL JOURNAL OF ACADEMIC RESEARCH IN BUSINESS AND SOCIAL SCIENCES Vol. 10, No. 7, July, 2020, E-ISSN: 2222-6990 @ 2020 HRMARS

Table 3: Use of the verbs Ser and Estar

\begin{tabular}{|c|c|c|}
\hline Subject & SER & Sentence Examples \\
\hline Yo (I) & $\begin{array}{l}\text { Soy } \\
(1 \mathrm{am})\end{array}$ & $\begin{array}{l}\text { Yo soy Qisya } \\
\text { I am Qisya }\end{array}$ \\
\hline Tú (you) & $\begin{array}{l}\text { Eres } \\
\text { (You are) }\end{array}$ & $\begin{array}{l}\text { ¿Tú eres Adni? } \\
\text { Are you Adni? }\end{array}$ \\
\hline $\begin{array}{c}\text { Él/ella/usted } \\
\text { (he, she and second person } \\
\text { (formal) }\end{array}$ & $\begin{array}{l}\text { Es } \\
\text { (You are }(f))\end{array}$ & $\begin{array}{l}\text { Ella es estudiante } \\
\text { She is a student }\end{array}$ \\
\hline Nosotros/as (we) & $\begin{array}{l}\text { Somos } \\
\text { (we are) }\end{array}$ & $\begin{array}{l}\text { Nosotros somos Malasios } \\
\text { (We are Malaysian) }\end{array}$ \\
\hline Vosotros/as (you) & $\begin{array}{l}\text { Sois } \\
\text { (You are }(p)\end{array}$ & $\begin{array}{l}\text { ¿ De dónde sois? } \\
\text { (Where are you from?) }\end{array}$ \\
\hline \multirow{8}{*}{$\begin{array}{l}\text { Ellos/ellas/ustedes } \\
\text { (they, second person plural } \\
\text {-formal) }\end{array}$} & $\begin{array}{l}\text { Son } \\
\text { they are }\end{array}$ & $\begin{array}{l}\text { Ellos son amables } \\
\text { (they are kind) }\end{array}$ \\
\hline & ESTAR & Sentence Examples \\
\hline & $\begin{array}{l}\text { Estoy } \\
\text { (I am) }\end{array}$ & $\begin{array}{l}\text { Estoy bien } \\
\text { (I am fine) }\end{array}$ \\
\hline & $\begin{array}{l}\text { Estás } \\
\text { (You are) }\end{array}$ & $\begin{array}{l}\text { ¿Estás nerviosa? } \\
\text { (Are you nervous?) }\end{array}$ \\
\hline & $\begin{array}{l}\text { Está } \\
\text { (You are (f)) }\end{array}$ & $\begin{array}{l}\text { Está mal } \\
\text { (He is not feeling well) }\end{array}$ \\
\hline & $\begin{array}{l}\text { Estamos } \\
\text { (we are) }\end{array}$ & $\begin{array}{l}\text { Estamos felices } \\
\text { (we are happy) }\end{array}$ \\
\hline & $\begin{array}{l}\text { Estáis } \\
\text { (You are }(p)\end{array}$ & $\begin{array}{l}\text { ¿Estáis en clase? } \\
\text { (Where are you? }\end{array}$ \\
\hline & $\begin{array}{l}\text { Están } \\
\text { (they are) }\end{array}$ & $\begin{array}{l}\text { Están estudiando } \\
\text { (They are studying). }\end{array}$ \\
\hline
\end{tabular}

There are many studies conducted on the errors of usage of verb Ser and Estar among non-native students who study Spanish as a foreign language. Ser and Estar are the two most frequently used verbs in SL (Real Academia Española, CREA, 2009) and these two verbs are not only confusing to children but also adults who are learning them (Silva-Corvalán and Montanari (2008). For example, Holtheuer and Short (2013) studied whether parents' correction input in the children's conversation using the verbs ser and estar could help children to speak using correct sentences. The results of this study showed that after correcting the use of ser and estar, children could use these verbs more accurately and grammatically. In SL, the sentence ella es bonita (she is beautiful) and ella está bonita 
(she is beautiful) is different. Ser bonita refers to the adjective/ nature (face) of a beautiful person, while estar bonita refers to the condition of someone who looks beautiful only when the sentence is said. If viewed, there is no difference in Malay language to reveal both situations. The differences between these functions confuse the students when they try to transfer their mother tongue habit to the target language.

\section{Research Methodology}

This study was conducted using the descriptive qualitative method. The data of this study consisted of written text produced by the respondents of the study, without obtaining any assistance from the teacher. The text analysis method was used to analyse the error of using verbs in students' writing based on pictures.

\section{Respondent of the Study}

Respondents of the study were 30 undergraduate students at Sultan Idris Education University, Tanjung Malim, Perak. The students took SL course Level I. Analysis of errors was made based on the students' writing, regardless of gender. These students had learned Spanish as a foreign language for a semester which consisted of 14 weeks of learning. Throughout the teaching and learning process, students had learned the SL verb structure and conjugation process to form grammatical sentences using the verb -ar, -er and -ir in present form. Besides, the students were exposed to the use of verb gustarse (indicating preferences) and the difference of verb Ser and Estar (to be) in sentences. Learning verbs in Level I syllabus covering the structure of regular and irregular verbs.

\section{Data of the Study}

The first stage of data collection was started with the development of a question paper to be answered by the students. The question paper developed was verified by a moderator who is a lecturer at the same university. The verification process was done to ensure that the level of the question was appropriate for the respondents' learning stage at that time. In the second stage, the respondents were given a question paper with five pictures. The respondents were required to construct sentences using Spanish verbs in 30 minutes. Students were not allowed to use any alternative assistance such as dictionaries or online translation platforms while answering the question. Upon completion of the question, the respondents submitted the question and answer papers to the instructor.

\section{Theory Application}

Error in sentence construction is common in the second language (L2) learning process. Dulay, Burt and Krashen (1982) said that most of the mistakes done by students who learned L2 were more specific to the language itself, as opposed to interference from their mother tongue. Students who learn L2 normally will obtain a simple structure first before successfully acquiring a more complex structure. To further explain mistakes often performed by students who studied L2, Dulay, Burt and Krashen (1982) had categorised the errors made by them into four categories which are the omission, addition, selection, and ordering. This classification is known as the Taxonomy of Error (Dulay, Burt \& Krashen, 1982). 
INTERNATIONAL JOURNAL OF ACADEMIC RESEARCH IN BUSINESS AND SOCIAL SCIENCES Vol. 10, No. 7, July, 2020, E-ISSN: 2222-6990 @ 2020 HRMARS

\section{Data Analysis and Discussion}

This section discusses the findings from data analysis. The key discussion is focusing on the forms of disorder and errors in using Spanish verbs in writing based on pictures. Based on the collected data, most of the respondents used common verbs, which had been learned in class to describe pictures in the given question. The total number of sentences produced by 30 students in the answer transcriptions was 420 sentences.

\section{Disorder of Verbs in Writing Sentences based on Pictures by Students}

The results showed that there were a lot of common verbs used by students in the answer scripts, for example, leer (read/reading), vivir (live), comer (eat), and so on. However, the most frequent verbs used with a high number of mistakes were gustarse, ser, tener, and estar. The most frequent verbs used by students and forms of errors in the use of the verbs are as follows:

Table 4: Types of Spanish verbs in the answer scripts

\begin{tabular}{l|c}
\hline Types of Spanish verbs & Frequency \\
\hline Gustarse & 30 \\
Ser dan Estar & 15 \\
Ser dan Tener & 7 \\
\hline
\end{tabular}

Table 4 shows the types and frequency of errors made by students in constructing sentences based on the given pictures. The most common error was the verb gustarse which was committed 30 times. The other verb errors involved the use of the ser and estar, which were committed 15 times and the use of verbs ser and tener for 7 times. Errors that occurred did not only involve the use of the verbs but also the errors of addition, reduction, selection, and ordering of verbs in the sentences produced.

Table 5: Forms of errors in the Spanish verbs in sentence writing based on pictures

\begin{tabular}{l|c}
\hline Forms of error & Frequency \\
\hline Conjugation & 40 \\
Reduction and addition & 62 \\
Incorrect selection of verbs & 32 \\
Ordering & 7 \\
\hline
\end{tabular}

In total, there were four forms of errors and disorder of the use of Spanish verbs in sentence writing by the respondents. The forms of errors were conjugation, error in the use of reflexive verb Gustarse, confusion in distinguishing the use of verb Ser and Estar and, confusion on the function of verb Ser and Tener. The error resulted in another error of unnecessary addition of elements, reduction of essential elements, improper selection of verbs, and inaccurate order in producing sentences. 
INTERNATIONAL JOURNAL OF ACADEMIC RESEARCH IN BUSINESS AND SOCIAL SCIENCES

Vol. 10, No. 7, July, 2020, E-ISSN: 2222-6990 @ 2020 HRMARS

\section{Verbs Conjugation Errors}

Examples of errors in Spanish verb conjugation are as follows:

Incorrect use of conjugation form:

i. Ellos es mi familia

ii. Ella eres cariñosa y trabajadora

iii. Ella leer estas novelas
Proper use of conjugation form:

- $\quad$ Ellos son mi familia (they are my family)

- Ella es cariñosa y trabajadora (She is beautiful and dilligent)

- Ella lee estas novelas (She reads/is Reading the novel)

The examples above show conjugation errors of Spanish verbs. In the answer scripts that were collected, it was found that students often committed errors by using the wrong forms of conjugation. For example, in sentence (i), the student chose the wrong form of conjugated verb based on the subject/doer who performed the action. Ellos es mi familia (they are my family) shows the error of using the base form of verb ser (to be). In the Spanish grammatical structure, the base form of verb ser, is a third-person plural when used with ellos (they), the resulting form of conjugation is son, not es, because es is a form of conjugation derived from the use of base verb ser with él (he) and ella (she) which are second-person singular, and usted (you) which is a formal second-person singular. Supposedly, in this situation, the respondent must use the correct form of conjugation, which is ellos son mi familia (they are my family).

The same error occurred in sentence (ii). In sentence (ii), the respondent used the base verb ser, but the referred subject was ella (she) which is third-person singular. As explained above, the base form of verb ser when used with a single third-person subject of él (he) and ella (she), the correct conjugation form is es. However, the respondent used the conjugated form of eres (you) which is used to refer to a second-person singular.

In sentence (iii), the respondent used the verb leer (read/reading) with ella (she), a third person singular. Leer is a regular verb, so conjugation must be done according to the regular change (refer to table 1). If the verb leer is conjugated with the third-person singular ella, then the correct form of the verb is lee (he reads/is reading). However, there was no conjugation of 'verb-subject' used by the students in the answer scripts. Instead, respondents used the infinitive verb ella leer estas novelas in the constructed sentences. In this situation, the sentence with the correct 'verb-subject' conjugated form and follows the structure of the SL grammar is ella lee estas novelas.

\section{Errors in Using Verb Gustarse}

The verb gustarse (to like) belongs to the category of reflexive verbs and it is used to express our interest and enjoyment in something. The verb gustarse must be used along with the reflexive pronoun me, te, le, nos, os, les (myself, yourself, himself, ourselves, yourselves and themselves). The reflexive verbs are used as a stand-alone. In other words, the Spanish reflexive verbs do not need to be conjugated with the subject/doer as the regular and other irregular verbs (refer to table 1 and 2). The conjugation form of verb gustarse with subject/doer should not be done as the conjugation of regular verbs and other irregular verbs. This verb conjugation only produces a singular (if the subject/doer is singular) and the plural form (if the subjects/doers are in plural). For example, Me 
gusta el chocolate (I like chocolate (singular subject) and me gustan los chocolates (I like chocolates (plural subject). Gustarse can also be used along with other base verbs. For example, Me gusta comer los chocolates (I like to eat chocolate). In this case, the verb that comes after the verb gustarse does no need to be conjugated and the infinitive verb is used. This causes the learners to be more erroneous and often the learners will conjugate the verb that comes after the verb gustarse and the learners also often leave the reflexive pronoun which should be used along with the verb gustarse. The use of the verb gustarse is as follows:

Table 6: Forms of verb conjugation gustarse

\begin{tabular}{|c|l|c|}
\hline Reflexive pronoun & Gustarse & Ejemplo \\
\hline (A mi)me (I) & gusta/gustan (like) & $\begin{array}{c}\text { Me gusta comer laksa (I like to eat } \\
\text { laksa) }\end{array}$ \\
\hline (A tí) te (you) & gusta/gustan (like) & $\begin{array}{c}\text { ¿Te gusta estudiar español? (Do you } \\
\text { like to learn Spanish?) }\end{array}$ \\
\hline ( A él /ella/usted) le(he) & gusta/gustan (like) & $\begin{array}{c}\text { Le gustan los chocolates (He likes to } \\
\text { eat chocolate) }\end{array}$ \\
\hline (A nosotros/as) Nos (we) & gusta/gustan (like) & $\begin{array}{c}\text { Nos gusta la naturaleza (we like } \\
\text { nature) }\end{array}$ \\
\hline (A vosotros/as) Os (you) & gusta/gustan (like) & $\begin{array}{c}\text { ¿Os gustan los gatos? (Do you like } \\
\text { cats?) }\end{array}$ \\
\hline (A ellos/ellas/ustedes) Les \\
(they)
\end{tabular}

The followings are some examples of mistakes done by students in the study:

\begin{tabular}{|l|l|}
\hline $\begin{array}{l}\text { Use of wrong conjugation forms of the verb } \\
\text { gustarse: }\end{array}$ & $\begin{array}{l}\text { Use of correct conjugation forms of the verb } \\
\text { gustarse: }\end{array}$ \\
\hline iv. Te gusta escuche música & $\begin{array}{l}\text { Te gusta escuchar música (You like to } \\
\text { listen to music) }\end{array}$ \\
\hline v. $\quad$ Te gusta practica deportes & $-\begin{array}{l}\text { Te gusta practicar los deportes (You love } \\
\text { to practice sports) }\end{array}$ \\
\hline vi. Amanda les gusta hablo porque... & $-\quad \begin{array}{l}\text { Amanda le gusta hablar porque ella es } \\
\text { profesora (Amanda likes to talk because...) }\end{array}$ \\
\hline
\end{tabular}

Sentence (iv), (v) and (vi) were verb conjugation of gustarse with base verb escuchar (hearing), practicar (practicing), and hablar (speaking) written by respondents in the answer scripts. Sentence construction using verb gustarse and base form as in the examples above was wrong, did not follow the structure of Spanish grammar and ungrammatical.

For example, in sentence (iv), the use of the reflexive pronoun and the conjugation form of verb gustarse was appropriate; the subject used was the second-person singular ' $t \mathrm{e}^{\text {' }}$ and verb conjugation of the gustarse in singular should be 'gusta'. However, respondents should not perform the conjugation process on base verb escuchar $\rightarrow$ te gusta escuchar música. Clearly, the respondent had 
again conjugated the base verb escuchar música $\rightarrow$ te gusta escuche, making the sentence constructed not only wrong in terms of the grammar but also did not have any grammatical meaning. Similarly, in sentence ( $v$ ) the respondent used the correct conjugation form of gustarse that coincided with the subject/doer of the verb $\rightarrow$ te gusta. However, the same error was committed when the respondent did not use the base verb practicar after the verb conjugation of gustarse, causing the sentence constructed to be grammatically wrong.

While the example in sentence (vi) contained errors not only on the verb conjugation form but also on the use of reflexive pronouns which incorrect. In this sentence, the subject or the doer was the third-person singular, and the correct reflexive pronoun is le. However, the respondent used les that referred to a third-person plural. The base verb hablar used was also incorrect because the respondent used a conjugated form rather than the infinitive form.

\section{Errors in using verb Ser and Estar}

These verbs are among the most widely used verbs in sentences (Real Academia Española, CRE, 2009). However, the use of Ser and Estar are confusing for students and they often use them wrongly in context. The wrong use in sentences leads to different meanings and raises misunderstanding and confusion. The followings are the errors in using verbs Ser and Estar in the sentences produced by the students based on the given picture:

Wrong use of the verb ser and estar:

vii. Ellos están mis amigos

viii. Ella está Sofía

ix. Ellos son feliz
Correct use of the verb ser and estar:

- $\quad$ Ellos son mis amigos (They are my friends)

- $\quad$ Ella es Sofía (She is Sofía)

- $\quad$ Ellos están felices (They feel very happy)

As explained in the previous paragraph, the verb ser and estar carry the same semantic intent which is 'to be' in English, and there is no comparable meaning in the Malay language. This is because, to explain about beautiful nature of oneself, for example, English uses the subject structure-verb 'to beadjectives:

$\begin{array}{lll}\text { Eliza } & \text { is } & \text { pretty } \\ \text { (subject) } & \text { (to be) } & \text { (adjective) }\end{array}$

However, to explain the concept of nature/character of a subject in Spanish, the verb ser is used:

$\begin{array}{lll}\text { Eliza } & \text { es } & \text { Guapa } \\ \text { (subject) } & \text { (to be) } & \text { (adjective) }\end{array}$

In contrast, to explain the same concept in Malay language, the verb 'to be' in the sentence is ellipsis:
Eliza
(subject) (to be) (adjective)
Cantic

Eliza cantik $\rightarrow$ there is no verb needed in Malay sentence to explain someone's nature.

To explain the location of a subject/doer at a certain time, English uses the same verb 'to be':

Eliza is In class 
INTERNATIONAL JOURNAL OF ACADEMIC RESEARCH IN BUSINESS AND SOCIAL SCIENCES

Vol. 10, No. 7, July, 2020, E-ISSN: 2222-6990 @ 2020 HRMARS

(subject) (to be) $\quad$ (preposition) (article)

However, in Spanish, the verb estar (to be) is used to explain the concept of the location of a subject/doer:

$\begin{array}{llccl}\text { Eliza } & \text { está } & \text { En } & \text { la } & \text { clase } \\ \text { (subject) } & \text { (to be) } & \text { (preposition) } & \text { (article) } & \text { (noun) }\end{array}$

Look at the next examples:

Pablo es guapo (Pablo is handsome) $\rightarrow$ verb ser (to be) is used to explain the nature/character of a subject.

Pablo está en casa (Pablo is at home) $\rightarrow$ verb estar (to be) is used to explain the location of a subject/doer at a certain time.

The use of two different verbs of ser and estar but carrying the same semantic intent makes the learners more erroneous and it encourages them to do mistakes in sentence construction. For example, in sentence (vii), (viii) and (ix).

Since ser and estar share the same semantic meaning but they are used in different contexts, educators need to explain that ser is regularly used, to talk about 'what'. Ser is normally used to describe traits, characters, occupations, properties and times, and estar is used to talk about 'how' and 'where'. In other words, estar is used to explain the circumstances, location, emotions, and actions within a certain period. Educators can give a few situations that use both verbs so that learners can differentiate them.

\section{Errors in Using Verb Ser and Tener}

In Spanish, the verb tener (to have) is used to describe two different concepts, which are, 1) to explain the rights and belongings; 2) to explain age. In contrast, to explain rights and belongings in English, the verb to have is used, while to be is used to talk about age. For example:

Table 7: The verb tener and the concept of use

\begin{tabular}{|l|c|c|c|}
\hline Concept & \multicolumn{3}{|c|}{ Verb } \\
\hline $\begin{array}{c}\text { Explaining the right and } \\
\text { belonging }\end{array}$ & Spanish language & English language & Malay language \\
& Tengo dos hermanos & to have & ada \\
\hline Explaining the age & tener & to be & $\begin{array}{c}\text { saya ada dua orang } \\
\text { abang }\end{array}$ \\
& Tengo 40 años & I'm 40 years old & $\begin{array}{c}\text { Saya berumur } \\
\text { tahun }\end{array}$ \\
\hline
\end{tabular}

Table 7 explains the concept and use of the verb tener and ser in SL. It is clear that English and Spanish use different verbs in describing the above two concepts. For Malaysian students who understand and speak English well, this will cause a bit of confusion in the application of appropriate verbs when explaining those concepts. Confusion and errors made by respondents can be seen in the following examples: 
INTERNATIONAL JOURNAL OF ACADEMIC RESEARCH IN BUSINESS AND SOCIAL SCIENCES Vol. 10, No. 7, July, 2020, E-ISSN: 2222-6990 @ 2020 HRMARS

Wrong use of the verb tener and ser:

\section{x. Él es 25 años}

\section{xi. Ibrahim tiene arrogante}

xii. Profesora tiene bonita y simpática
Correct use of the verb tener and ser:

- $\quad$ Él tiene 25 años (She is 25 years old)

- Ibrahim es arrogante (Ibrahim is arrogant)

- $\quad$ La profesora es bonita y simpática (She is a beautiful and kind tecaher)

The use of verb ser in sentence $(x)$ was wrong because the situation that wanted to be conveyed was about a person's age. As stated above, SL uses verb tener to explain the concept of age, but English uses the verb to be. In this case, the influence of English confused the students and they could not use the correct verb to describe the concept of age in SL.

Sentenced (xi) and (xii) indicated the same feature of error which was the use of the verb tener to describe a person's trait/personality/character/nature. In this situation, the respondent clearly used the wrong verb, because SL uses the word ser to explain the concept of trait/character as described earlier.

The use of the verb tener was clear but when the verb was used to explain a person's age and condition, the student would wrongly use it with the verb ser. Educators can directly correct the error for learners to be aware that the verb ser cannot be used to describe age and someone's eternal nature or character. In this case, the English translation should not be used at all. Students need to be exposed to different types of sentences and situations so that all confusion can be answered, and mistakes can be avoided.

\section{Errors in Verb Addition}

According to the Taxonomy of Errors (Dulay, Burt \& Krashen, 1982), addition referred to the prevalent use of certain rules. Errors can occur as a result of regularisation, overlook, exception, application of something that is not in its place, and putting unnecessary elements.

\begin{tabular}{|l|l|}
\hline Unnecessary addition of verbs: & Use of correct verbs: \\
\hline xiii. Ellos son comen & $-\quad$ Ellos comen (they eat) \\
\hline$x i v$. él es hacer deporte & $-\quad$ Él hace deporte (he plays sports) \\
\hline$x v$. él es cantar & $-\quad$ Él canta (he sings) \\
\hline
\end{tabular}

The addition involves the use of two verbs in a single sentence. For example, in sentence (xiii), ellos son comen showed the addition of conjugation form of verb ser for the third-person plural son (they are) in the sntence ellos comen (they eat). The sentence ellos son can be constructed but requires an object or complement to complete it. For example, ellos son amables (they are good) and ellos son de Malasia (they come from Malaysia). However, the sentence ellos comen can be constructed without a complement. In Malay language, this sentence is called as intransitive verbs without complement. Sentence (xiv) and (xv) also showed the addition of verb conjugation for the thirdperson singular es (he is/she is). However, the student did not conjugate the verb hacer (make/do) for a single third-person which was él (he) to be grammatical as él hace deporte (he does sports activities) and cantar to be canta. 
INTERNATIONAL JOURNAL OF ACADEMIC RESEARCH IN BUSINESS AND SOCIAL SCIENCES Vol. 10, No. 7, July, 2020, E-ISSN: 2222-6990 @ 2020 HRMARS

\section{Verbs Reduction}

Hazlina Halim (2011) said that the error of reduction happened due to the respondent's direct thoughtlessness to the attribution of a certain element that needs to be present along with the words used. For example, the use of verb gustarse, other than committed error on the base verb conjugation in a sentence, students also often left the reflexive pronoun and this aspect of reduction occurred because students left out the function words compared to the content words that carried meaning. Examples of reduction that occurred are as follows:

\begin{tabular}{|l|l|}
\hline $\begin{array}{l}\text { Reduction of the reflexive pronoun with verb } \\
\text { gustarse: }\end{array}$ & $\begin{array}{l}\text { Correct use of the reflexive pronoun and verb } \\
\text { gustarse: }\end{array}$ \\
\hline xvi. ellos gustan comer & $-\quad$ Ellos les gustan comer (they like eating) \\
\hline xvii. ella gusta bailar & $-\quad$ Ella le gusta bailar (she likes dancing) \\
\hline $\begin{array}{l}\text { xviii. él es guapo y gusta cantar hacer en su } \\
\text { tiempo libre }\end{array}$ & $\begin{array}{l}\text { Él es guapo y le gusta cantar en su tiempo } \\
\text { libre (He is handsome and likes to sing } \\
\text { during free time) }\end{array}$ \\
\hline
\end{tabular}

The above sentences show the error of reflexive pronoun reduction in sentences that used the verb gustarse which were les and le. Ellos gustan comer had a reflexive pronoun reduction les and ella gusta bailar also had a reduction of le before the verb gusta. El es guapo y gusta cantar hacer en su tiempo libre also experienced a reflexive pronoun reduction of le before the verb gustar but, the use of the next verb which was cantar (singing) was correct. However, there was an element of addition to the third verb which was hacer (making) that was not required in this sentence and this addition made the sentence ungrammatical.

\section{Wrong Selection of Verbs}

Wrong selection of verbs Correct selection of verbs

xix. Ella está sophea

- Ella es Sophea (She is Sophea)

xx. Mi hermana están muy romanticos - Mi hermana es muy romantica

(My sister is very romantic)

xxi. Ella juega el piano

- Ella toca el piano (She plays piano)

Error in verbs selection in the above sentences involved verbs that shared the same semantic meaning which were verb ser and estar (to be) as well as the verb jugar and tocar (play/playing). Some students were confused with the use of these verbs and considered that they can be used in both contexts (sports and musical instruments). The selection of verb ser and estar cannot be exchanged with one another because each of these verbs, has a different syntax function even they have the same semantic meaning (refer to the above description). It is similar to jugar which is used to explain playing sports equipment/sports training while tocar is used to explain about play musical instruments. Students had done the generalization process, by applying the rules in Malay language by using the verb 'bermain' or 'play' in English that can be used in both contexts to write Spanish sentences.

\section{The Error of Verb Order}

The error of verb order refers to the placement of a word that is not in the place. This study found that students had made mistakes of writing verbs not in order which caused the sentences produced to be ungrammatical. 
INTERNATIONAL JOURNAL OF ACADEMIC RESEARCH IN BUSINESS AND SOCIAL SCIENCES

Vol. 10, No. 7, July, 2020, E-ISSN: 2222-6990 @ 2020 HRMARS

Examples are as follows:

Error of verb order:

xxii. El futbol es jugador

Correct order of verb:

- Él es un jugador de futbol

xxiii. Nosotros nos comparti con la familia

(He is a football player)

- Nosotros compartimos con la familia

xxiv. Ellos con amigos charlan.

(We share with the family)

- Ellos charlan con los amigos

(They chat with friends)

The finding shows that the students made mistakes in constructing sentences using verbs. For example, in sentence (xxii), the verb es (to be) should come after the pronoun Él (he) not after the noun futbol. The sentence produced by students had an illogical meaning which is 'the ball is a player' and it was not grammatical as it was not referring to the person as a player. On the other hand, sentence (xxiii) referred to the conjugated verb for the third-person plural which was compartimos. The students might make a spelling error of mos to be nos and put the word before the verb compartir; share.

Those verbs need to be written in a single word and not separately such as the verb gustarse and need to be written after the pronoun nosotros (us). In the next sentence, Ellos con amigos charlan showed an error in the position of the verb charlan which was placed at the end of the sentence even verb was supposed to come after the pronoun ellos. The sentence is called putting a part of the predicate before the subject in Malay language, but such a sentence is ungrammatical in SL and should be corrected.

To strengthen the understanding of verb conjugation, students should be exposed to as much as possible the use of verbs in different contexts of sentences. The links between verb conjugation and subjects or doers should be explained more often to remind the students that a change to a suffix of an infinitive verb is dependent on the subject of the action. The instructor can also show a YouTube video on ways to conjugate regular verbs, for example,

https://www.youtube.com/watch?v=yQhIJylksSA and discuss the types of errors done by students so that the same error is not repeated. Thus, it can help to minimise the error. It is also suggested to the instructor to continue making corrections and enlighten the students when errors are being made so that errors can be improved. According to a study done by Holtheuer and Short (2013), corrections done immediately can help students to learn. 
Table 8: Example of Spanish verbs used in Blog

Lihat gambar di bawah untuk kegunaan kata kerja dalam ayat.

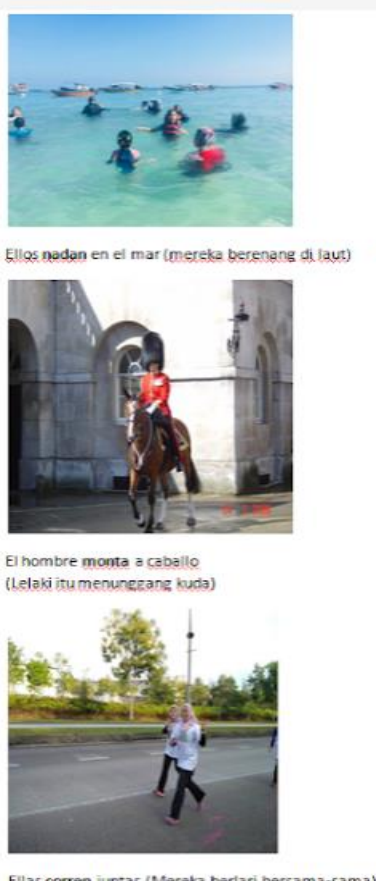

Ellas corren juntas (Mereka berlari bersamä-sama)

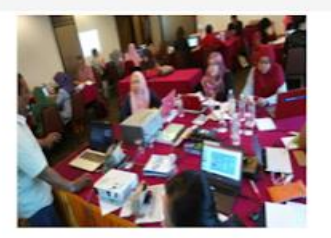

Nosotros trabajamos mucho (kami bekeria kuat)
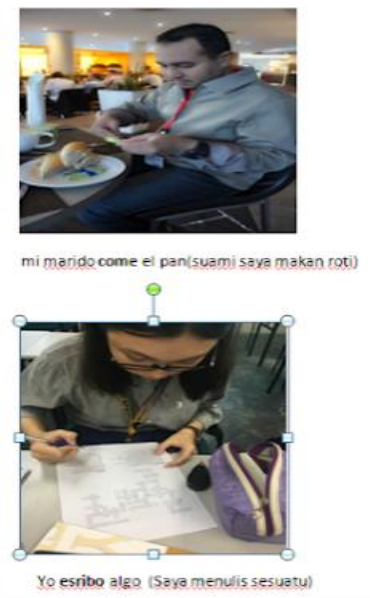

\section{Conclusion}

The results of the study showed that verb disorder occurred particularly on the various forms of verb conjugation based on the subject (doer) and number, the use of verb Ser, Estar, Tener, and reflexive verb of Gustar. This confusion caused grammatical errors, ungrammatical sentences, the addition of unnecessary verbs, reduction of the important elements, incorrect verbs selection, and inaccurate order in sentence construction. The most common error was the verb gustarse which was committed 30 times. The other verb errors involved the use of the ser and estar, which were committed 15 times and the use of verbs ser and tener for 7 times. To strengthen the understanding of verb conjugation, the use of the verb Ser, Estar, Tener and Gustarse students should be exposed to as much as possible the use of verbs in different contexts of sentences. The links between verb conjugation and subjects or doers should be explained more often to remind the students that a change to a suffix of an infinitive verb is dependent on the subject of the action. The instructor can also show a you tube video on ways to conjugate regular verbs and discuss the types of the errors done by students so that the same error is not repeated. Thus, it can help to minimise the error. It is also suggested to the instructor to continue making corrections and enlighten the students when errors are being made so that errors can be improved. Corrections done immediately can help students to learn. Since ser and estar share the same semantic meaning but they are used in different contexts, educators need to explain that ser is regularly used, to talk about 'what'. and estar is used to talk about 'how' and 'where'. Educators can give a few situations that use both verbs so that learners can differentiate them. Grammatical errors and spelling errors also can be checked using Generic Spelling Checkers such as the one included in Microsoft word, Spanishcheckers, Language Tools and Stilus. The spell checkers tested in previous study have a high frequency of error detection, detecting more than $85 \%$ of the spelling errors in essays written by SFL students. This also might make the self-correction work 
INTERNATIONAL JOURNAL OF ACADEMIC RESEARCH IN BUSINESS AND SOCIAL SCIENCES

Vol. 10, No. 7, July, 2020, E-ISSN: 2222-6990 @ 2020 HRMARS

less complicated for the SFL learner (Blanquez and Fan, 2019). All aspects related to verbs need to be mastered by the learners and failure to understand this aspect in the correct context will lead to failure in generating grammatical sentences and inaccuracy in terms of the meaning. Therefore, the input derived from the data of the students' writing is expected to provide useful ideas and information to Spanish language teachers to improve the teaching and learning of SL. Besides, educators can systematically arrange their teaching materials to suit the students' level. Online teaching medium can also serve as an interesting application to increase the interest and understanding of students.

\section{References}

Blanquez, M., Fan. C. (2019). The Efficacy of Spell Check Packages specifically designed for second languages learners of Spanish. Pertanika Journal of Social Science and Humanities, 27(2), 847861.

Brown, D. H. (2000). Principles of language learning \& teaching. (4th ed.). New York: Longman.

Dictionary Real Academia Española, (CREA, 2009). Nueva Gramatica de la Lengua Española. Madrid: Espasa.Vol. 1

Dulay, H. C., Burt, M., Krashen, S. (1982). Language two. New York: Oxford University Press.

Hassan, H., Omar, M. S., \& Abdul Wahid, P. R. (2018). Kecelaruan Morfologi dalam Penulisan Bahasa Melayu oleh Penutur Asing. Jurnal Linguistik, 22(2), 020-036.

Hassan, R. (2010). Analisis Kesilapan Sistem Bunyi Bahasa Perancis. In Mohd Azidan Abdul Jabar. My Language Your Language Bahasaku Bahasamu, (pp. 182-196). Serdang: Universiti Putra Malaysia

Holtheuer, C., \& Rendle-Short, J. (2013). Ser and estar: Corrective input to children's errors of the Spanish copula verbs. First Language, 33(2), 155-167.

Ismail, S., \& Sim, T. S. (2016). Aktiviti Pengaturan Menggunakan Zone of Proximal Development dalam Menstruktur Ayat Bahasa Sepanyol. GEMA Online ${ }^{\circledR}$ Journal of Language Studies, 16(3) , 167185. http://doi.org/10.17576/gema-2016-1603-11

Karim, N. S., Onn, F. M., Musa, H. H., \& Mahmood, A. H. (2010). Tatabahasa Dewan. (3 ${ }^{\text {rd }}$ ed.). Kuala Lumpur: Dewan Bahasa dan Pustaka.

Nor, M. M., Na, T. L., \& Md. Salleh, N. (2019). Kepekaan dan kefahaman pelajar terhadap aplikasi gender gramatikal dalam pembinaan ayat bahasa Sepanyol. Perspektif: Jurnal Sains Sosial Dan Kemanusiaan, 11(2), 15-25

Nor, M. M., Reduzan, N. H., \& Ismail, S. (2018). Isu dan Kesilapan Gender Gramatikal dalam Pembelajaran Bahasa Sepanyol sebagai Bahasa Asing di IPTA. Jurnal Bahasa, Bil 36, 71-93

Omar, M. S., Rahmat, A., \& Yusof, Y. M. (2017). Menyulam Budaya Dalam Pengajaran Bahasa Melayu untuk Penutur Asing. Jurnal Linguistik, 21(2), 081-092.

Silva-Corvalán, C., \& Montanari, S. (2008). The Acquisition of Ser, Estar (and be) by Spanish English bilingual child: 'The Early Stages'. Bilingualism: Language and Cognition. 11, 341-368. http://doi.org/10.1017/S136672890900357X

Vasquez, E. M. (2017). Problems in verb conjugation in Spanish among Malaysian Chinese students: A case study. Journal of Modern Languages, 17(1), 109-128. 